\title{
特集 「各種病態における栄養管理・治療の最近の展開」
}

\author{
高齢者の食事管理 \\ 渡 邊 健 太郎 \\ 日本大学医学部内科学系糖尿病代謝内科学分野
}

Nutritional Management in the Elderly

Kentaro Watanabe

Division of Diabetes and Metabolic Diseases, Department of Internal Medicine, Nihon University School of Medicine

\begin{abstract}
The nutritional status of elderly people tends to be affected by comorbidities and individual differences. Malnutrition increases the risk of progression and development of sarcopenia and frailty in the elderly, less than 75 years of age. Further, malnutrition influences quality of life, such as the instrumental activities of daily living, mental state, and cognitive function, and shortens the healthy life span in elderly people. Hence, eligible comprehensive geriatric assessments, including nutrition assessment, are needed before establishing a management plan for malnutrition in elderly people. Appropriate management to prevent malnutrition must be planned in consideration of the individualized clinical, social, economical and familial features. Nutritional management in elderly people against developing the sarcopenia and frailty contributes to the prevention of impairment of quality of life and shortness throughout the healthy life span.
\end{abstract}

Key words: elderly, malnutrition, sarcopenia, frailty, protein-energy malnutrition

高齢者, 低栄養, サルコペニア, フレイル, PEM

(J. Nihon Univ. Med. Ass., 2019; 78 (4): 215-221)

要旨 高齢者の栄養状態は併存疾患や個人差の影響を 受けやすい. 75 歳以上の高齢者では栄養障害はサルコ ペニアおよびフレイルの発症および進展のリスクとな る。さらに，栄養障害は ADL，精神心理状態，認知機 能などの QOL 低下のリスクを増大させる。それゆえ， 高齢者では栄養障害の治療計画を立てる前に栄養評価を 含めた高齢者総合機能評価を行うのが必要である。高齢 者の栄養障害に対する適切な対策は個別的に臨床的, 社 会的，経済的，家庭的背景を考慮して計画されなければ ならない。高齢者のサルコペニア，フレイル予防の食事 管理は健康寿命の障害および生命予後の短縮の予防に貢 献する.

\section{はじめに}

高齢者の栄養管理は，過栄養と低栄養に対する対策に 大きく分かれる. 65 歳以上 75 歳未満の前期高齢者（准 高齢者）は壮年者と同様に心血管病発症予防のため, 肥 満の是正や生活習慣病管理に基づいた栄養管理が必要で ある。一方で 75 歳以上の後期高齢者（高齢者）では, 健康寿命維持のためのフレイル・サルコペニアの発症お よび進展予防のための栄養管理が中心になってくる.

本稿では，高齢者の特徵および特有な問題点を考慮し た食事管理について概説する。

\section{1. 高齢者の栄養状態および体格の特徵}

高齢者のエネルギー摂取量は壮年群と比し少ない。厚 生労働省の「平成 29 年度 国民健康·栄養調査」では, 総エネルギー摂取量は 20 歳代から徐々に増加し, 男女 とも 60 歳代で最も高くなるが, 70 歳代および 80 歳代 で減少してくる，三大栄養素の変化に関しては蛋白質お よび脂質は 70 歳代以上の高齢者では減少するが, 炭水

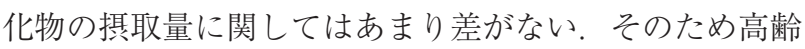
者では蛋白質および脂質の摂取量低下がエネルギー摂取 量の低下に寄与していると考えられる.

体格の加齢性変化について, 「平成 29 年度 国民健 康・栄養調査」では, BMI 25 以上の者の割合は男女と も50歳代をピークに 60 歳代以降低下している. しか し, 同時に 70 歳以上でも BMI 25 以上の過栄養による 肥満やメタボリックシンドロームを合併する高齢者が存 在することが示されている，ただし，高齢者ではBMI のみで体格や内臓脂肪蓄積のリスクを評価するには注意 が必要である，高齢者では身長が減少するために BMI が実際より高值になる場合がある。さらに高齢者では低 栄養, 心不全, 腎不全が合併し, 浮腫を合併することも あり， BMI が体脂肪を正確には反映しないことがある。 また加齢に伴い BMI が変化しなくてもウエスト周囲長 が増加する腹部肥満を有する高齢者が増加する。一方で, BMI 20 未満の低栄養傾向の者の割合は 70 歳代以上で増 加の傾向を示し, 85 歳以上では男性 23.9\%, 女性 34.3\% 
と急激に増加する。これは栄養摂取障害を伴ったフレイ ルを有する高齢者が増加することが背景にあると考えら れる。

\section{2. 高齢者の低栄養の特徵と問題}

高齢者の低栄養の原因・背景としては経口摂取量の低 下や活動性の低下だけではなく，併存疾患，薬剤性， 腔機能低下, 精神心理的変化, 社会環境や経済的問題な どの様々な背景が重なって生じていることが多い (Table $1)^{1)}$. 特に高齢者では基礎疾患に対する治療で多剤併用 となる場合が多く，薬物による食欲低下には注意が必要 である。また，咀嚼機能低下による経口摂取の障害を オーラルフレイルと呼び, 放置しておくと食欲低下, 低 栄養を生じ, サルコペニア, フレイルのリスクが増加す る.さらに精神心理的変化も低栄養を引き起こすリスク となる。認知機能障害やそれに伴う感覚低下（味覚, 知 覚など）や食欲低下の他, うつ, 誤嚥に対する恐れや不 安が経口摂取不良を生じるリスクになる ${ }^{2)}$ 。貧困などの 経済的問題や独居や高齢世带などの社会環境も低栄養の リスク因子である。経済的困窮は食事の多様性を失わせ, 安価なファストフード食や弁当などの摂取が多くなり, 糖質・脂質摂取過多や蛋白摂取量低下につながる。独居

Table 1 Risk factors for developing malnutrition in elderly

\begin{tabular}{l}
\hline ·認知機能障害、うつ状態 \\
-嚥下障害 \\
·独居、要介護(食事介助, 買物や家事ができない) \\
·多剂薬物服用(副作用) \\
-胃腸障害(便秘や下痢) \\
-口腔内の問題(義歯の不具合など) \\
-経済的問題 \\
·臓器機能の低下(腎不全、慢性呼吸器疾患など) \\
·併発する感染症、癌、糖尿病の存在 \\
\hline
\end{tabular}

日本臨牀 2018; 76(増刊号 5): 644-647 より引用
あるいは高齢夫婦世帯は社会的なつながりが希薄になり 孤独感が増すことなどが，抑うつや ADL 低下を引き起 こし，食欲低下や低栄養につながる，ADLの低下と栄 養状態は密接な関係性があり，低栄養はさらなる ADL の低下を引き起こす。デイケアセンター通所中の高齢 者の介護度別の栄養状態を簡易栄養状態評価表 (Mini nutrition assessment: MNA) を調査した報告では，要介護 度が高いほど，MNA 17 点未満の栄養不良を合併する割 合が増加することが示されている゙リ。

高齢者の低栄養のタイプは蛋白・エネルギー栄養障害 (protein-energy malnutrition: PEM) を示すことがほとんど である。本邦では地域在住者での PEM の頻度は $8.9 \%$ と 報告されている。しかし，病院外来通院者では約 $10 \%$, 入院高齢患者では約 $40 \%$, 急性期病院の入院高齢患者 では約 30\%,さらに在宅診療を受けている高齢者では $35 \%$ と急性期疾患や要介護状態を伴う高齢者では PEM の頻度が増加する3)。 また, フレイルと PEMの関連を 報告した研究ではフレイルの高齢者では $58.0 \%$ が PEM を合併していた ${ }^{4)}$ ，高齢者は併存疾患の存在，急性疾患 の発症やフレイルがPEMのリスクをなることが示され ている. PEM はマラスムス型 PEM とクワシオコル型 PEM があり $(\text { Table } 2)^{5)}$, 高齢者ではこれらが混在してい る. PEM は免疫能や生態修復機能が障害されているた め，遷延化しやすく，骨格筋の重度な減少を来した悪液 質状態までに進行した場合はPEM の改善はさらに困難 となる。PEM は様々な有害な病態を引き起こし，低栄 養のさらなる進行を促し, 死亡リスク上昇につながる. 在宅高齢者の栄養障害と死亡リスクを調査した報告では, BMI 17.0 未満と血清アルブミン值 $3.5 \mathrm{~g} / \mathrm{dl}$ 未満の高齢者 は死亡リスクが有意に上昇しており ${ }^{6)}$, 後期高齢者の栄 養障害は死亡リスクを有意に上昇させる。そのため，低 栄養を生じる可能性のある高齢者は早期に栄養状態の評 価を行い，適切な低栄養対策を行うことが必要である。

Table 2 Classification of protein-energy malnutrition (PEM)

\begin{tabular}{lccc}
\hline & クワルシコール & マラスムス & 混合型 \\
\hline 栄養欠乏 & 蛋白質 & エネルギー·蛋白質 & エネルギー·蛋白質 \\
体重減少 & 標準体重の 60 ～80\% & 標準体重の $60 \%$ 下 & 標準体重の $60 \%$ 下 \\
貧血 & あり & あり & あり \\
浮腫 & あり & なし & あり \\
皮膚の状態 & 湿·皮膚炎 & 乾燥性 & 湿·皮膚炎 \\
下瘌 & あり & あり & あり \\
食欲 & なし & あり & なし \\
精神障害 & あり & なし & あり \\
血清アルブミン & 低下 & 正常 & 低下 \\
血清中脂質 & 低下 & やや低下 & 低下 \\
ミネラル類 & 不足状態 & 不足状態 & 不足状態 \\
ビタミン類 & 不足状態 & 不足状態 & 不足状態 \\
\hline
\end{tabular}

臨床透析 2008; 24: 127-133 より引用. 


\section{3. 高齢者の低栄養とサルコペニア・フレイルの関連}

栄養障害はサルコペニア発症のリスク因子である 本邦のサルコペニアの疫学では，住民コホートで 10〜 $20 \%$ 程度の有病率であると報告されている ${ }^{7,8)}$. サルコ ペニアと栄養の関連性では，エネルギー摂取量，蛋白質 摂取量，バリン・アルギニンなどの筋肉合成関連アミノ 酸摂取量の低下が発症リスクとなる。さらに，悪液質状 態ではサルコペニアを合併することが多く，骨格筋の萎 縮に先行した脂肪萎縮が生じる。一方でメタボリックシ ンドロームとサルコペニアが合併したサルコペニア肥満 といわれる病態もみられる。このような病態では内藏脂 肪の蓄積，耐糖能障害，脂質異常症，高血圧症を合併 し，動脈硬化や全身の代謝障害が進行している可能性が 高い. サルコペニアは身体活動量低下から総エネルギー 消費量の低下を引きおこし，食事量の減少と低栄養を招 くリスクが高い。その結果として体重減少，筋力低下に 加え，易疲労感，歩行速度の減少，身体活動の低下が連 鎖，悪循環しフレイルに進行する（フレイルサイクル） (Fig. 1) $)^{9)}$. フレイルでは老化に伴う様々な予備能の低下 により, 疾病発症や身体機能障害に対する脆弱性が増
し，死亡リスクが増加する。フレイルと低栄養の関連性 では, ビタミン, 蛋白質, アミノ酸および食物摂取量低 下との関連が指摘されている ${ }^{10)}$ 。フレイルに関連する低 栄養を評価する指標として, 体重減少率, アルブミン, トランスサイレチン，トランスフェリン，レチノール結 合蛋白，血清コレステロール值を用いるのが有用である $(\text { Table } 3)^{11)}$ ．高齢者のサルコペニア．フレイル対策はフ レイルサイクルの連鎖を断ち切ることが中心であり，低 栄養の改善を含めた包括的アプローチが必要である。

\section{4. 高齢者の栄養評価へのアプローチ}

高齢者の栄養評価法としては，主観的方法と客観的方 法を用いて栄養障害に程度を評価するのが一般的であ る。主観的方法のスクリーニング法としては主観的包括 アセスメント (Subjective Global Assessment: SGA) がある. SGA で，中等度から高度の栄養不良と評価された際に は客観的スクリーニングを行うと良い。高齢者の客観 的栄養障害評価法は MNA が有用である (Fig. 2). MNA の簡易版である MNA-SF も有用である。併せて栄養障 害，サルコペニア，フレイルのリスクとなる生活機能障

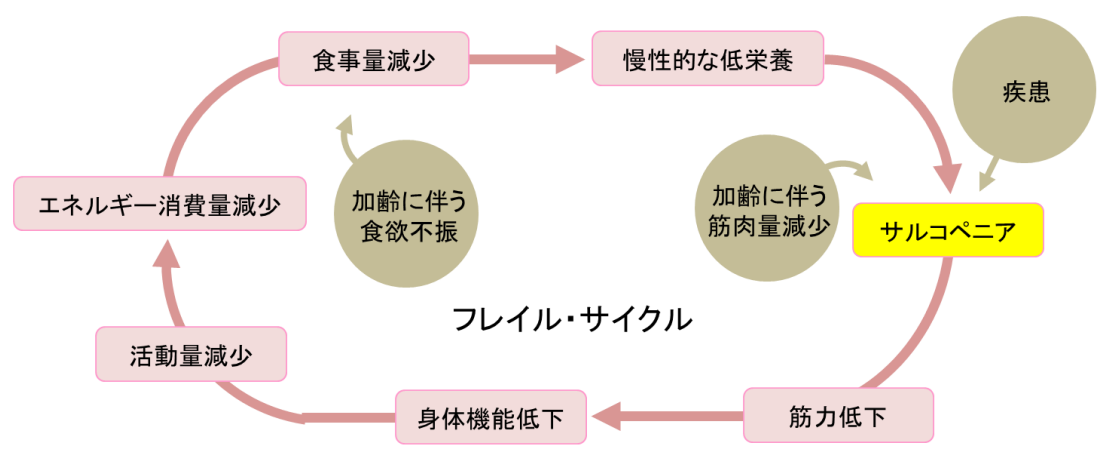

Fig. 1 Relationship between sarcopenia and frailty (cycle of frailty). J Gerontol A Bilo Sci Med Sci 2008; 63: 984-990 より引用.

Table 3 Criteria of malnutrition associated with frailty in elderly

\begin{tabular}{|c|c|c|c|c|}
\hline \multicolumn{5}{|c|}{ 1)身体計測 } \\
\hline \multicolumn{5}{|c|}{ 体重減少率: (平常時体重一現在の体重) $\div$ 平常時体重 $\times 100(\%)$} \\
\hline 期間 & \multicolumn{2}{|c|}{ 軽度〜中等度の栄養障害 } & \multicolumn{2}{|c|}{ 中等度以上の栄養障害 } \\
\hline 1カ月 & \multicolumn{2}{|l|}{5 \%未満 } & \multicolumn{2}{|c|}{$5 \%$ 以上 } \\
\hline 3力月 & \multicolumn{2}{|l|}{$7.5 \%$ 未満 } & \multicolumn{2}{|c|}{$7.5 \%$ 以上 } \\
\hline 6力月 & \multicolumn{2}{|l|}{10 \%未満 } & \multicolumn{2}{|c|}{$10 \%$ 以上 } \\
\hline \multicolumn{5}{|c|}{ 2) 血液データ } \\
\hline & & \multicolumn{2}{|c|}{ 低栄養基準値 } & 半減期 \\
\hline \multicolumn{2}{|l|}{ アルブミン } & \multicolumn{2}{|c|}{$3.5 \mathrm{mg} / \mathrm{dL}$ 未満 } & 17〜23日 \\
\hline \multicolumn{2}{|c|}{ プレアルブミン(トランスサイレチン) } & \multicolumn{2}{|c|}{10 mg/dL未満 } & 1.9日 \\
\hline \multicolumn{2}{|c|}{ トランスフェリン } & \multicolumn{2}{|c|}{200 mg/dL未満 } & 7〜10日 \\
\hline \multicolumn{2}{|c|}{ レチノール結合蛋白 } & \multicolumn{2}{|c|}{$3.0 \mathrm{mg} / \mathrm{dL}$ 未満 } & 0.5日 \\
\hline \multicolumn{2}{|c|}{ 血清総コレステロール } & \multicolumn{2}{|c|}{$150 \mathrm{mg} / \mathrm{dL}$ 未満 } & \\
\hline
\end{tabular}

健康長寿ハンドブック 2011 より引用. 


\section{主篗的包括的評価採点用紙}

患者の氏名

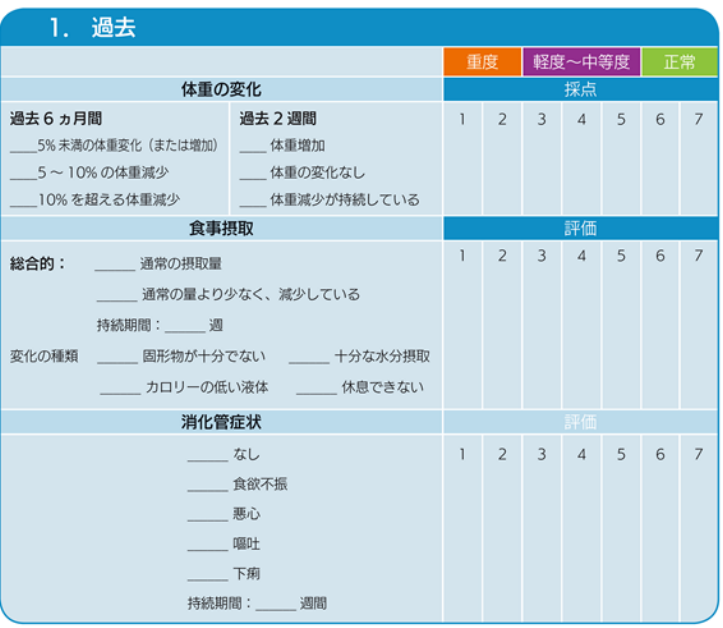

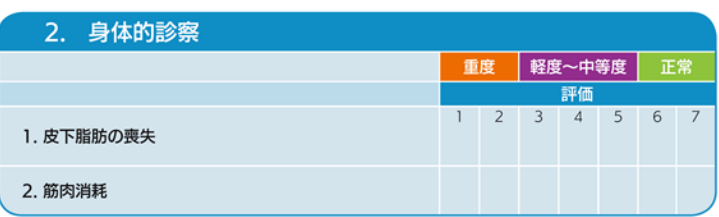

\section{2. 総合的 SGA 分類}

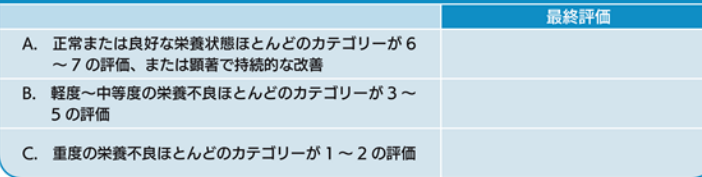

https://nutritionmatters.jp/common/pdf/tools/ClinicalHandbook WithPracticeTools.jp.pdf より記載
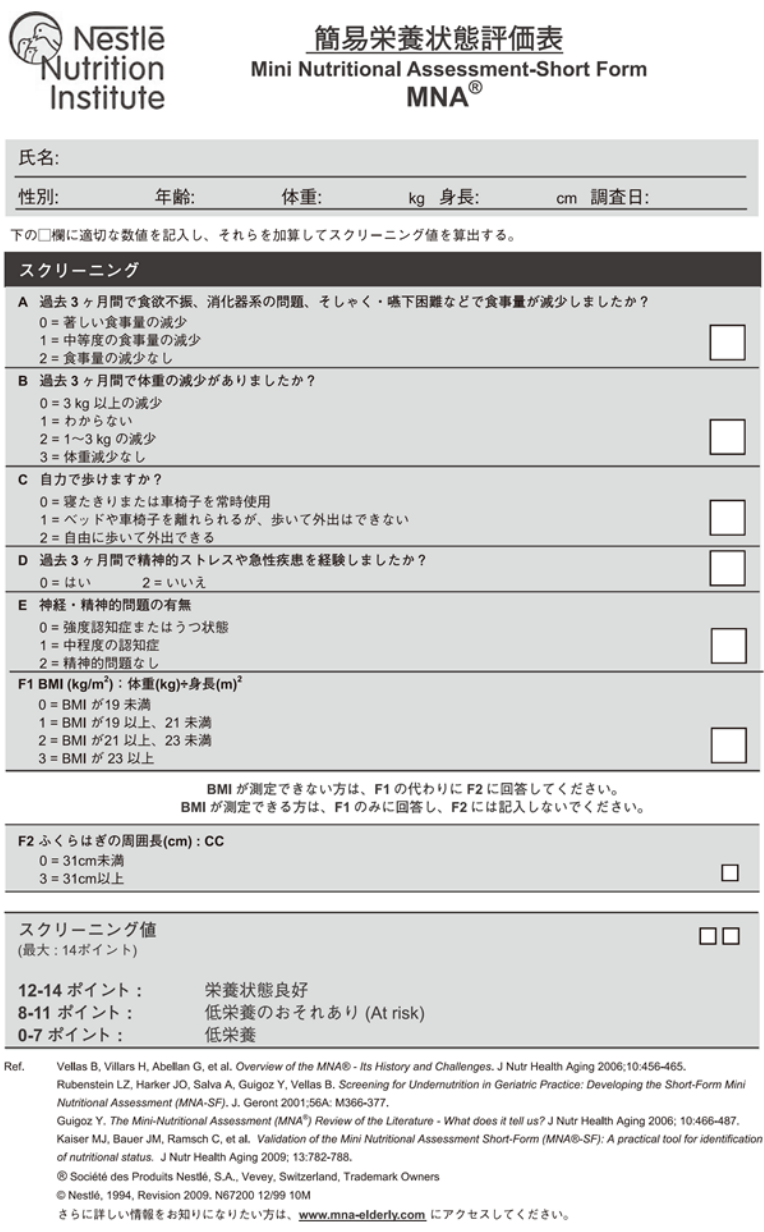

https://www.mna-elderly.com/mna_forms.html より記載

Fig. 2 Nutrition assessment sheet.

害の有無を高齢者総合機能評価 (Comprehensive Geriatric Assessment: CGA) で評価し, 問題点がある場合はでき るだけ介入を検討する。CGAの評価としては簡易版の CGA-7 が有用である (Table 4) ${ }^{12)}$. SGA, MNA， CGA-7 を用いて栄養障害の程度とそのリスク因子を継続的に評 価し介入を継続することが, 栄養障害発症および進行を 予防するために必要である。

\section{5. 高齢者の低栄養への栄養介入}

高齢者の栄養計画の作成については壮年者と同様に必 要な総エネルギー量を計算し, 適切な糖質, 脂質, 蛋白 質，微量元素およびビタミン量を決定する。また，栄養 の投与経路や水分量も併せて検討する. 総エネルギー量 を計算する方法としては, Harris-Benedictの推定式が有 用であり，それにストレス係数や行動係数を乗じて算出 されたものを用いるのが良い。ただし，Harris-Benedict の推定式は 70 歳までを対象にした計算式であり，高齢 者では参考值となる。蛋白摂取量に関しては高齢者では 壮年者と比べ総エネルギー数の摂取が少ないため, 蛋白
摂取量が少なくなりやすい。骨格筋量筋量の減少の予防 のためには健康な高齢者では $1.0 \sim 1.2 \mathrm{~g} / \mathrm{kg} /$ 日，慢性ある いは急性疾患を罹患している高齢者では $1.2 \sim 1.5 \mathrm{~g} /$ 日の 蛋白質摂取量が良い ${ }^{13)}$ 。アミノ酸の投与の目安は重症感 染症や腎不全時などを除き，投与非蛋白熱量/投与窒素 量比 (non-protein calorie/nitrogen: NPC/N) 150 前後を目安 として設定する。窒素量は投与蛋白質量 $(\mathrm{g}) / 6.25$, 投与 非蛋白熱量は総エネルギー量から蛋白質 $(\mathrm{g}) \times 4 \mathrm{kcal}$ を引 いた值でそれぞれ計算する。糖質および脂質量は総エネ ルギー量のそれぞれ 50〜 65\%，20～30\%の割合で決定 する。作成した栄養計画に基づき実際に栄養の投与を開 始し，定期的に栄養状態の再評価を行い，必要な場合は 栄養計画を再考する。また，高齢者で長期間低栄養が続 いた症例の栄養投与を行う場合は refeeding syndrome の 発症に注意が必要である。 Refeeding syndromeはリン欠 そ症とビタミン B1 欠乏症により, 循環器, 呼吸器, 腎, 中枢神経, 消化器の多彩な症状が出現する。さらに乳酸 アシドーシス，高血糖，低血糖などの代謝異常も呈す る。重症例では心停止などで死亡することもある。対策 
Table 4 CGA-7

\begin{tabular}{|c|c|c|c|c|}
\hline 番号 & CGA7 の質問 & 評価内容 & 正否と解釈 & $\begin{array}{l}\text { 次への } \\
\text { ステップ }\end{array}$ \\
\hline \multirow[b]{2}{*}{ (1) } & $\begin{array}{l}\text { <外来患者> } \\
\text { 診察時に被験者の挨拶を待つ }\end{array}$ & \multirow[b]{2}{*}{ 意欲 } & $\begin{array}{l}\text { 正 : 自分から進んで挨拶する } \\
\text { 否 : 意欲の低下 }\end{array}$ & \multirow[b]{2}{*}{$\begin{array}{l}\text { Vitality } \\
\text { index }\end{array}$} \\
\hline & $\begin{array}{l}\text { <入院患者・施設入所者>自ら定時に起床する } \\
\text { か, もしくはリハビリのの積極性で判断 }\end{array}$ & & $\begin{array}{l}\text { 正: 自ら定時に起床する, またはリハビ } \\
\text { リその他の活動に積極的に参加する } \\
\text { 否：意欲の低下 }\end{array}$ & \\
\hline (2) & $\begin{array}{l}\text { 「これから言う言葉を繰り返して下さい（桜, } \\
\text { 猫, 電車)」」「「聞きますから覚え } \\
\text { ておいて下さい」 }\end{array}$ & 認知機能 & $\begin{array}{l}\text { 正 : 可能 (できなければ(4)は省略) } \\
\text { 否 : 復唱ができない） 難聴, 失語などが } \\
\text { なければ中等度の認知症が疑われる }\end{array}$ & $\begin{array}{l}\text { MMSE } \cdot \\
\text { HDS-R }\end{array}$ \\
\hline \multirow[b]{2}{*}{ (3) } & $\begin{array}{l}\text { ＜外来患者〉 } \\
\text { 「ここまでどうやって来ましたか?」 }\end{array}$ & \multirow[b]{2}{*}{$\begin{array}{l}\text { 手段的 } \\
\text { ADL }\end{array}$} & \multirow{2}{*}{$\begin{array}{l}\text { 正 : 自分でバス, 電車, 自家用車を使っ } \\
\text { て移動できる } \\
\text { 否 : 付き添いが必要 } \Rightarrow \text { 虚弱か中等度の } \\
\text { 認知症が疑われる }\end{array}$} & \multirow[b]{2}{*}{ IADL } \\
\hline & $\begin{array}{l}\text { <入院患者・施設入所者> } \\
\text { 「普段バスや電車, 自家用車を使ってデパート } \\
\text { やスーパーマーケットに出かけますか?」 }\end{array}$ & & & \\
\hline (4) & 「先程覚えていただいた言葉を言って下さい」 & 認知機能 & $\begin{array}{l}\text { 正 : ヒントなしで全部正解. 認知症の可 } \\
\text { 能性は低い } \\
\text { 否: 遅延再生（近時記憶）の障害 } \Rightarrow \text { 軽 } \\
\text { 度の認知 } \\
\text { 症が疑われる }\end{array}$ & $\begin{array}{l}\text { MMSE } \cdot \\
\text { HDS-R }\end{array}$ \\
\hline (5) & $\begin{array}{l}\text { 「お風呂は自分ひとりで入って, 洗うのに手助 } \\
\text { けは要りませんか」 }\end{array}$ & \multirow{2}{*}{$\begin{array}{l}\text { 基本的 } \\
\mathrm{ADL}\end{array}$} & \multirow{2}{*}{$\begin{array}{l}\text { 正 : 6は, 失禁なし, もしくは集尿器で } \\
\text { 自立. 入浴と排泄が自立していれは他の } \\
\text { 基本的ADLも自立していることが多い } \\
\text { 否: 入浴, 排泄の両者がメ } \Rightarrow \text { 要介護状 } \\
\text { 態の可能性が高い }\end{array}$} & \multirow{2}{*}{$\begin{array}{l}\text { Barthel } \\
\text { index }\end{array}$} \\
\hline (6) & $\begin{array}{l}\text { 「失礼ですが, トイレで失敗してしまうことは } \\
\text { ありませんか?」 }\end{array}$ & & & \\
\hline (7) & 「自分が無カだと思いますか？」 & $\begin{array}{l}\text { 情緒· } \\
\text { 気分 }\end{array}$ & $\begin{array}{l}\text { 正 : 無カと思わない } \\
\text { 否 : 無カだと思う～うつの傾向がある }\end{array}$ & GDS-15 \\
\hline
\end{tabular}

日老医誌 2005; 42: 177-180 より引用.
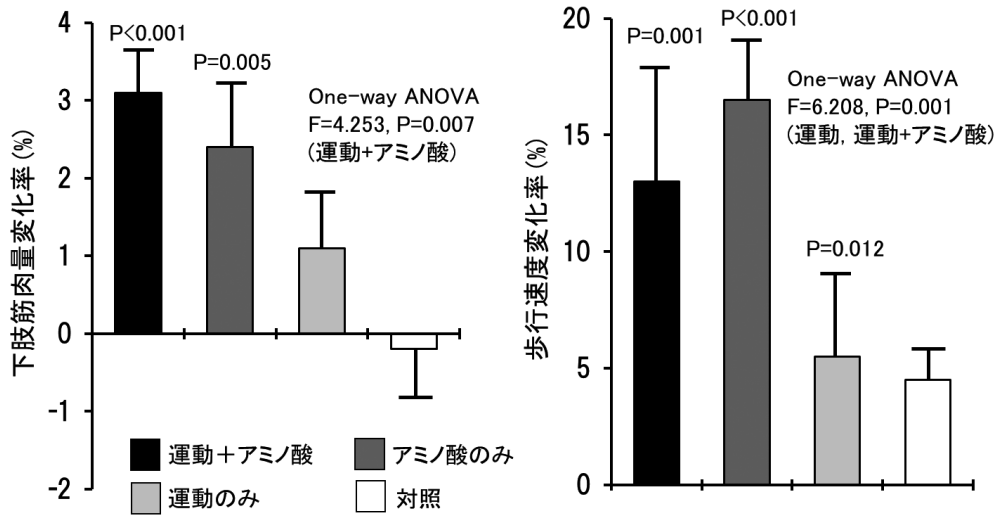

75 歳以上の155例の女性を運動+ロイシン

Fig. 3 Effects of amino acid and exercise on leg muscle mass and walking speed. Clin Nutr 2014; 33: 929-936 より引用。

としては，現体重 $(\mathrm{kg}) \times 5 \sim 10 \mathrm{kcal} /$ 日程度の少量の投 与エネルギー量から開始し、リンなどの微量元素やビ夕 ミン不足があれば補充を行う。経静脈栄養では refeeding syndromeの発症リスクが高いため，なるべく経口・経 腸栄養とする。100～ $200 \mathrm{kcal} /$ 日ずつ投与エネルギー量 を増やしていく，同時に採血データや理学所見等にモ二 タリングも同時に行い, refeeding syndrome 発症予防に 努める.

サルコペニア・フレイル発症予防対策としても栄養計 画の作成が有用である。米国の高齢者の蛋白質摂取量と
3 年間の筋肉量変化の関連性を検討した報告では，蛋白 摂取量が低いほど，筋肉量の減少量が多い結果が示され た ${ }^{14)}$ 、サルコペニア，フレイル対策は主にレジスタンス トレーニングとロイシン中心のアミノ酸投与が有用であ る。本邦での 75 歳以上の高齢者で運動療法およびロイ シン中心のアミノ酸を摂取し，下肢の筋肉量および歩行 速度の改善度を前向きに評価した介入研究では，運動療 法とアミノ酸摂取の併用群は改善効果が高いことが報告 されている $(\text { Fig. } 3)^{15)}$. そのほかビタミン D 投与も有用 であると報告されている ${ }^{16)}$. 


\section{6. 高齢者の生活習慣病への栄養介入}

高齢者では壮年時からの長い期間で身に着いた食習慣 を改善するのは難しいことを念頭に置いて栄養指導を行 う必要がある。画一的な栄養指導はかえって食欲不振や 極端な蛋白質摂取の低下などの栄養素バランスの崩壊を 招き，栄養障害を引きおこす場合があるため注意が必要 である。

肥満に関しては，前期高齢者では壮年者と同様にメ夕 ボリックシンドロームが心血管病発症リスクとなるた め ${ }^{17)}$, 肥満に対する介入が必要である. 特に生活習慣病,

脂肪肝，心血管病既往，睡眠時無呼吸症候群など肥満に 伴う健康障害を合併する高齢者では, 減量が必要であ る。ただし，後期高齢者ではメタボリックシンドローム が心血管病の発症リスクとなるか否かは議論の余地があ るので後期高齢者の肥満介入については個別の判断が必 要である.

糖尿病については，1 日の摂取エネルギー量は加齢に 伴う基礎代謝量および身体活動量の低下を考慮すると標 準体重 $1 \mathrm{~kg}$ あたり 25〜30 kcal で指導する。ただし，高 齢者のエネルギー消費量は個人差があるので経過をみな がら増減すると良い。ただし, サルコペニア，フレイル があり，低栄養あるいはそのリスクがある患者では比較 的多めのエネルギー摂取量が望ましい. 栄養素のバラン スは壮年群と同じと考えて良いが, 炭水化物の摂取不良 や過剩摂取にならない様注意し，十分な蛋白質を摂取す ると良い ${ }^{18)}$.

高血圧症に対して塩分制限は有用である。高齢者にお いても一般住民および糖尿病患者を対象としたJDCS 研 究では, ナトリウム摂取量の低下で心血管疾患の発症を 減少したことが示されている ${ }^{19)}$ 。ただし, 過度の減塩は 大量発汗時などに脱水や低血圧の誘因となることがある。 高齢者は加齢による潜在的な味覚の低下があり, 減塩に より味が極端に変化すると, 食事摂取量の低下を来す場 合があるため注意が必要である。高齢者高血圧症患者で も過度の飲酒は壮年者と同様に心血管病発症に関連する ため，中等度以上のアルコールを摂取している場合は節 酒を指導する ${ }^{20)}$.

高齢者の CKD で蛋白制限に関してのエビデンスはそ しい. 顕性アルブミン尿がない 2 型糖尿病患者 6,213 人 (平均年齢 65 歳) の追跡調査で蛋白質摂取の最も低い群 は, 最も高い群と比較して eGFR が $5 \% /$ 年以上低下した と報告されている ${ }^{21)}$. さらに高齢者で CKD 進行例はサ ルコペニア，フレイルリスクが上昇する。特に eGFR 30 未満の患者ではフレイルリスクが有意に上昇するとさ れている ${ }^{22)}$ ，高齢者で蛋白制限を行う症例では総エネル ギー量が十分摂取できている（30〜35 kcal/kg/日）場合 のみ蛋白制限をするとよい. CKD 診療ガイドでは高齢 者では $0.8 \mathrm{~g} / \mathrm{kg} /$ 日を目安とした蛋白質摂取制限が推奨さ れている.

\section{おわりに}

高齢者の食事管理は壮年者と比し, 年齢や QOL を考 慮した栄養指導を行い，栄養障害に介入することが必要 である。本邦では健康寿命と平均寿命の差は男女とも 10 年前後あり，高齢者の健康長寿を延長させる観点か らも高齢者の栄養障害のリスクを減らすための適切な栄 養管理が必要である。

本総説に関して申告すべき利益相反はありません.

\section{文献}

1）小川澄人.【老年医学 (上) - 基礎 ·臨床研究の最新動向 -】高齢者の症候 低栄養・体重減少。日本臨牀 2018; 76(増刊号 5): 644-647.

2) Ogawa S. Nutritional management of older adults with cognitive decline and dementia. Geriatr Gerontol Int 2014; 14 (Suppl 2): 17-22.

3) Izawa $S$, Kuzuya M, Okada $K$, et al. The nutritional status of frail elderly with care needs according to the mini-nutritional assessment. Clinical Nutrition 2006; 25: 962-967.

4) Kuzuya M, Kanda S, Koike T, et al. Evaluation of MiniNutritional Assessment for Japanese frail elderly. Nutrition 2005; 21: 498-503.

5）伊藤美紀子。腎不全医療における栄養管理の基礎知識 栄養スクリーニング 栄養不良の定義. 臨床透析 2008; 24: 127-133.

6) Kitamura $K$, Nakamura $K$, Nishiwaki $T$, et al. Low body mass index and low serum albumin are predictive factors for short-term mortality in elderly Japanese requiring home care. Tohoku Exp Med 2010; 221: 29-34.

7) Yamada M, Nihsiguchi S, Fukutani N, et al. Prevalence of sarcopenia in community-dwelling Japanese older adults. $\mathrm{Am}$ Med Dir Assoc 2013; 14: 911-915.

8) Simokata H, Ando F, Yuki A, et al. Age-related changes in skeletal muscle mass among community-dwelling Japanese: a 12-year longitudinal study. Geriatr Gerontol Int 2014; 14 (Suppl 1): 85-92.

9) Xue QL, BAndeen-Roche K, Varadhan R, et al. Initial manifestations of frailty criteria and the development of frailty phenotype in the Women's Health and Aging Study II. J Gerontol A Bilo Sci Med Sci 2008; 63: 984-990.

10) Lorenzo-López L, Maseda A, de Labra C, et al. Nutritional determinants of frailty in older adults: A systematic review. BMC Geriatrics 2017; 14: 108.

11）栄養. 健康長寿ハンドブック, p48-53, メジカルレビュー 社, 2015 年 3 月

12）鳥羽研二. 高齢者総合的機能評価ガイドライン。日老医 誌 2005; 42: 177-180.

13) Deutz NE, Bauer JM, Barazzoni R, et al. Protein intake and exercise for optimal muscle function with aging: recommendations from the ESPEN Expert Group. Clin Nutr 2014; 33: 929-936.

14) Houston DK, Nicklas BJ, Ding J, et al. Dietary protein intake is associated with lean mass change in older, communitydwelling adults: the Health, Aging, and Body Composition (Health ABC) Study. Am J Clin Nutr 2008; 87: 150-155.

15) Kim HK, Suzuki T, Saito K, et al. Effects of exercise and amino acid supplementation on body composition and physical 
function in community-dwelling elderly Japanese sarcopenic women: a randomized controlled trial. J Am Geriatr Soc 2012; 60: 16-23.

16) Englund DA, Kirn DR, Koochek A, et al. Nutritional Supplementation With Physical Activity Improves Muscle Composition in Mobility-Limited Older Adults, The VIVE2 Study: A Randomized, Double-Blind, Placebo-Controlled Trial. J Gerontol A Biol Sci Med Sci 2017; 73: 95-101.

17) Denys K, Cankurtaran M, Janssens W, et al. Metabolic syndrome in the elderly: an overview of the evidence. Acta Clin Belg 2009; 64: 23-34.

18）高齢者糖尿病の食事療法. 高齢者糖尿病診療ガイドライ ン 2017, p49-53, 南江堂, 2017 年 6 月.

19) Horikawa C, Yoshimura Y, Kamada C. Dietary sodium intake and incidence of diabetes complications in Japanese patients with type 2 diabetes: analysis of the Japan Diabetes Complications Study (JDCS). J Clin Endocrinol Metab 2014; 99: 36353643.

20）高齢者高血圧診療ガイドライン 2017． 日老医誌 2017; 54: $236-237$.

21) Dunkler D, Dehghan M, Teo KK, et al. Diet and kidney disease in high-risk individuals with type 2 diabetes mellitus. JAMA Intern Med 2013; 173: 1682-1692.

22) Lee S, Lee S, Harada K, et al. Relationship between chronic kidney disease with diabetes or hypertension and frailty in community-dwelling Japanese older adults. Geriatr Gerontl Int 2017; 17: 1527-1533. 